\title{
China and the Global Economic Order
}

A Discreet Yet Undeniable Contestation

\section{Françoise Nicolas}

Translator. David Buchanan

\section{(2) OpenEdition}

\section{Journals}

\section{Electronic version}

URL: http://journals.openedition.org/chinaperspectives/6960

DOI: 10.4000/chinaperspectives.6960

ISSN: 1996-4617

\section{Publisher}

Centre d'étude français sur la Chine contemporaine

\section{Printed version}

Date of publication: 1 June 2016

Number of pages: 7-14

ISSN: 2070-3449

\section{Electronic reference}

Françoise Nicolas, «China and the Global Economic Order », China Perspectives [Online], 2016/2 | 2016,

Online since 01 June 2016, connection on 28 October 2019. URL : http://journals.openedition.org/ chinaperspectives/6960 ; DOI : 10.4000/chinaperspectives.6960 


\title{
China and the Global
}

\section{Economic Order}

\author{
A Discreet Yet Undeniable Contestation
}

FRANÇOISE NICOLAS

\begin{abstract}
Having long remained a passive presence within multilateral economic organisations, China recently changed its stance when the United States was faced with a major financial crisis. The present article re-examines China's recent initiatives in matters of global economic governance from a long-term perspective. From this analysis it will emerge that in parallel with its economic takeoff, China has progressively shifted from a stance in favour of the global economic order - as defined and imposed following the Second World War - to a simple reformist approach that did not fundamentally challenge the established order, and then more recently to an increasingly overt revisionist approach, accompanied by the establishment of new institutions under Chinese influence. That being said, while China's strategy is becoming more offensive, it remains fundamentally experimental in nature and the end goal remains unclear. Under the current conditions, it is far from certain that we are heading for a new global economic order where China rules supreme.
\end{abstract}

KEYWORDS: global governance, international financial institutions, WTO, IMF, BRICS, internationalisation of the yuan.

\section{Introduction}

A ttempts to impose a new global economic order are not a recent phenomenon. In the 1960s and '70s, developing countries tried to achieve this within the framework of the United Nations Conference on Trade and Development (UNCTAD), but in the absence of a credible leader they did not have much success. Recently, it seems that China has launched a new offensive with this in mind, seeking, if certain analysts are to be believed, to impose its own vision as the world's second-largest economic superpower, with the intention of becoming the first. Having supported the Beijing Consensus instead of the Washington Consensus, China ${ }^{(1)}$ may be in the process not only of reshaping, but also of redefining the global economic order, by establishing new institutions such as the Asian Infrastructure Investment Bank (AllB).

How can China's change in stance be explained, when until now it has kept a relatively low profile? How are we to interpret this, and what might be the consequences? What is the exact nature of these initiatives? Can we in fact speak of the emergence of a new, Chinese-style global economic order? These are the questions that this article will endeavour to answer.

With that in mind, the article will re-examine China's recent initiatives within a longer-term perspective. First of all, it will give an overview of China's strategy in the face of the global economic order as defined and imposed following the Second World War, then it will look at how China's position in matters of international economic governance has evolved in tandem with its economic take-off, and finally it will analyse the various initiatives taken recently by Beijing, in order to determine whether we really are heading for a new global economic order dominated by China.

\section{China and the international economic order of Bretton Woods: (2) From collaboration to contestation}

\section{China, beneficiary of the Bretton Woods Agreement}

Throughout the whole period of development and reform (which began in the late 1970s), China remained largely marginalised from the governance of international economic order as defined by Western powers in the wake of the Second World War. Nor indeed did it attempt to challenge this order: in fact, China even seemed quite comfortable with an economic order ruled by America and the West, be it in a commercial or a monetary capacity.

As a result, China was able to benefit considerably, for example, from aid from the World Bank. After joining the institution in 1980, the People's Republic of China (PRC) became one of the institution's main "clients," borrowing over $\$ 40$ billion over the course of a quarter of a century, and subsequently funding nearly 300 investment projects, with one of the highest success rates ever recorded by the institution. ${ }^{(3)}$ Although this financial

1. In this article, the term "China" refers exclusively to the People's Republic of China.

2. For a more detailed analysis of the evolving relationship between China and international trade governance, see Henry Gao, "From the Periphery to the Centre: China's Participation in WTO Negotiations," China Perspectives, No. 2012/1, pp. 59-65, and Françoise Nicolas, "La Chine et les institutions économiques multilatérales, entre révisionnisme et statu quo" (China's role in multilateral economic institutions: Between revisionism and status quo), Politique étrangère, No. 2014/3, pp. 49-61.

3. China successively drew on resources from the International Development Association (IDA) (until 1999), then on resources from the International Bank for Reconstruction and Development (IBRD). After becoming an upper-middle income economy, China used aid from IBRD for small-scale projects, and itself became a contributor to the IDA fund. 
aid was considerable, it still accounted for less than $1 \%$ of total investment in the country, and in terms of investment per capita remained far below what had been observed in other developing countries. For this reason, it could not be held responsible for the country's strong economic performance.

As well as receiving financial aid from the World Bank, the PRC also benefited from its technical assistance services and training activities. Interestingly - and surprisingly - enough, the Bank has never curtailed China in its choice of economic policy, having accepted right from the start that China's development strategy would be a unique case. ${ }^{(4)} \mathrm{A}$ report published in 2007 examines in detail China's contributions to the institution, alongside the benefits that the PRC received through its cooperation with the Bank. ${ }^{(5)}$

Relations between China and the International Monetary Fund (IMF) were no more complex. While China never received financial assistance from the Fund, ${ }^{(6)}$ it was nevertheless able to take full advantage of cooperating with the institution by making regular use of its technical assistance services, and by holding regular consultations on its options for macroeconomic policy. In fact, China regularly followed the recommendations it was given, for example by devaluing the yuan in 1986. (7)

Given their ideological differences, it was therefore surprising that China tended more frequently to side with the IMF than with the institution's detractors. ${ }^{\left({ }^{8}\right)}$ Hence, during the 1997-1998 Asian financial crisis, China did not take up the cause of the Asian Monetary Fund (AMF), which could have undermined the IMF's control of the international monetary system. Admittedly, the fact that the project originated in Japan was enough to make it an unattractive prospect for Beijing, but there is little doubt that China's passivity while discussions were under way made it much easier for the United States to torpedo the initiative. Likewise, China did not join in with the large number of Asian countries that came together in their searing criticism of the IMF's management of the crisis. ${ }^{(9)}$

Finally, given the extrovert nature of its development strategy, China also complied relatively willingly with the demands imposed by its trade partners in the lead-up to its accession to the World Trade Organisation (WTO). ${ }^{(10)}$ In joining, China's leaders at the time were given the ability to push for quite a few reforms, given that the industrial nations had demanded far stricter requirements of China than of any other economy before allowing them to attain membership. China can, incidentally, be considered one of the chief beneficiaries of the Organization's creation. Since then, it has played along with the WTO's game, broadly respecting the rules, even if its behaviour doesn't always match up to its commitments. Nevertheless, China gives its support to the Organization, taking part not only in trade negotiations, including certain multilateral agreements, ${ }^{(11)}$ but also by participating in the dispute settlement mechanism and by accepting the WTO's decisions in these matters. ${ }^{(12)}$

During its period of economic take-off, it was surprising that China did not play a leading role in global governance, as its leaders were entirely preoccupied with issues of internal development. Generally, China accepted the institutions as they were, and simply sought to take full advantage wherever possible.

\section{China's growing power and the first signs of contestation}

After a period of consistent double-figure growth, it was unavoidable that the Chinese economy should disrupt the worldwide balance of power. Based on GDP expressed in Purchasing Power Parity, China moved from $11^{\text {th }}$ to first place between 1980 and 2015, even if at current exchange rates America's GDP remains very clearly in the lead (with $\$ 17,416$ billion compared to China's $\$ 10,355$ billion). ${ }^{(13)}$

This disruption of the global economic order is not only connected to China's significant growth, but also to the methods by which it has integrated with the global economy. For instance, China's largely export-based growth strategy allowed the country to clear a systematic surplus from the balance of its current transactions, which coupled with a surplus in the capital account fuelled principally by a massive influx of foreign investments allowed it to accumulate colossal monetary reserves and led to a global financial imbalance, which has long been blamed as a major cause of instability. The challenge for China is to manage these savings that give the country such unequalled financial influence, while for the rest of the world the challenge is to find a way to work around this new situation.

Under these conditions, it's only natural that China would seek, on the one hand, to step out from under the wing of the international financial institutions (IFIs) and on the other hand to increase its role in global governance.

\section{- Initial tensions over managing the exchange rate}

The value of a country's currency (and therefore the management of its monetary policy) is an eminently political matter over which tensions can easily arise. The powerful growth of emerging Asian economies and the competition this creates for the markets of hitherto dominant economies have perhaps predictably been met with accusations of manipulating exchange rates and undervaluing currency. China has been no exception to this rule.

While the analysis and advice of the IMF's economists had always been mostly positive regarding Beijing's conduct with economic policy, the trend was reversed between 2000 and 2010, with tensions mounting over the issue of managing the yuan. Pressure exerted by the Fund in favour of reevaluating the Chinese currency ${ }^{(14)}$ was met with vigorous resistance by the Chinese authorities, who between 2007 and 2009 decided to block publication of the results of Article IV consultations by the Fund. ${ }^{(15)}$ These early

4. Pieter Bottelier, "China and the World Bank: How a Partnership Was Built," Stanford Center for International Development, Working Paper No. 277, April 2006.

5. World Bank, China and the World Bank:A Partnership for Innovation, Washington DC, World Bank, 2007.

6. In 1981 and 1986, the PRC did, however, draw on its IMF credit tranche in order to consolidate its currency reserves.

7. Margaret Pearson, "China's Integration into the International Trade and Investment Regime," in Elizabeth Economy and Michel Oksenberg (eds), China Joins the World: Challenges and Prospects, New York, Council on Foreign Relations, 1999, pp. 161-205.

8. China's position as a creditor is undoubtedly connected to this state of affairs.

9. Yu Yongding, "IMF Reform: A Chinese View," in Edwin Truman (ed.), Reforming the IMF for the $21^{\text {st }}$ Century, Special report 19, Peterson Institute for International Economics, Washington, DC, 2006, pp. 519-525.

10. China joined the WTO in 2001, after almost a decade of liberalisation efforts and reform. For more on this, see Will Martin, "L'adhésion à l'OMC et les réformes économiques en Chine" (China: Economic reform and the WTO), Politique étrangère, No. 2, 2004, pp. 331-346.

11. Such as, for instance, the Ministerial Declaration on Trade in Information Technology Products (ITA).

12. For more details on this, see Henry Gao, "From the Periphery to the Centre: China's Participation in WTO Negotiations," art. cit.

13. While China accounted for less than 2\% of the global CDP (in current dollars) in 1980, by 2011 its share had increased to $8 \%$.

14. This pressure was in line with criticisms of China made by certain American economists, particularly those at the Peterson Institute for International Economics in Washington (Morris Goldstein, John Williamson, C. Fred Bergsten), who accused Beijing of manipulating its currency and keeping it consistently undervalued in order to keep exports competitive.

15. Peter Ferdinand and Jue Wang, "China and the IMF: From Mimicry towards Pragmatic International Institutional Pluralism," International Affairs, Vol. 89, No. 4, 2013, pp. 895-910. 
Table 1 - IMF - 15 highest voting shares, before and after the 2010 reforms (in \%)

\begin{tabular}{|l|l|l|l|}
\hline \multicolumn{2}{|c|}{ Pre-reform } & \multicolumn{2}{c|}{ Post-reform } \\
\hline United states & 17.661 & United States & 6.461 \\
\hline Japan & 6.553 & Japan & 6.390 \\
\hline Germany & 6.107 & China & 5.583 \\
\hline France & 4.502 & Germany & 4.225 \\
\hline United Kingdom & 4.502 & France & 4.225 \\
\hline China & 3.994 & United Kingdom & 3.159 \\
\hline Italy & 3.305 & Italy & 2.749 \\
\hline Saudi Arabia & 2.929 & India & 2.705 \\
\hline Canada & 2.670 & Russia & 2.315 \\
\hline Russia & 2.493 & Brazil & 2.311 \\
\hline India & 2.441 & Canada & \\
\hline Netherlands & 2.164 & Saudi Arabia & 2.095 \\
\hline Belgium & 1.931 & Spain & 1.999 \\
\hline Brazil & 1.782 & Mexico & 1.868 \\
\hline Spain & 1.687 & Netherlands & 1.831 \\
\hline
\end{tabular}

Source: IMF, www.imf.org (accessed on 5 April 2016).

signs of dissent marked the beginning of a less peaceful period between Beijing and the IMF.

\section{- Challenging the internal governance of the IMF}

Buoyed up by its growing economy, China (and with it all the other large emerging economies, particularly the other BRICS - Brazil, Russia, India, and South Africa) would campaign to reform the way IFls functioned, in particular to redistribute IMF voting shares in order to better represent the new balance of power within the global economic order. These voting shares play a crucial role, not only in determining the maximum amount of financial resources a country commits to provide to the IMF, but also in its access to Fund resources and its say in the institution's decision-making process.

Finally, after a series of long and arduous discussions that took place, notably, within the $\mathrm{G} 20$, an agreement was reached in 2010 not only to double the total number of voting shares, but also to transfer $6 \%$ of voting rights from "developed countries" to "under-represented countries," and also to emerging countries and countries undergoing vigorous development (the majority of which were Asian).

China was the big winner of this debate: the reassignment of voting shares meant that its share rose from $3.9 \%$ to $6.4 \%$ of the total, and that it became the IMF's third-largest stakeholder, behind the United States (17.4\%) and Japan (6.5\%), but ahead of Germany (5.6\%), France, and Great Britain (4.2\% each). ${ }^{(16)}$ Alongside China, three other BRICS countries (Brazil, India, and Russia) were also among the top ten shareholders. Reform remained modest because China's voting share was still far from representative of its influence on the global economy, but it did at least take the new balance better into account. All the same, it could in no way be said to fundamentally challenge the ideological principles of the institution.

Rather surprisingly, especially since they lost nothing in the reallocation, the United States initially refused to ratify the reform, thus preventing it from being implemented. In fact, where decisions as important as this are concerned (regarding the internal governance of the institution) it is necessary to obtain a majority vote of $85 \%$, ${ }^{(17)}$ so, with $17.4 \%$ of the voting shares, the United States holds a blocking minority (which gives them de facto veto power). Despite repeated pressure from its peers, the United
States refused to give in. In April 2015, in a report published following the annual spring meetings of the IMF and World Bank, it reiterated that "the urgent implementation" of this reform was its "top priority," without actually putting it into action: just 145 member states, accounting for $77 \%$ of all voting shares, supported reform. It wasn't until 18 December 2015 that the United States finally acquiesced and gave the green light, meaning reform could be implemented.

In summary, in the wake of its transformation into an economic superpower, China's stance shifted towards a more resolute desire to reform the international monetary system. Nonetheless, China's various initiatives existed within a paradigm of reforming the existing system only marginally, without questioning its ideology or fundamentally challenging it in any way. Recent years have seen a new trend appear: China has begun to take an increasingly offensive stance, marked by a degree of revisionism. ${ }^{(18)}$

\section{China's new initiatives}

\section{Reforming the international monetary system}

First, China's stance in matters of financial cooperation would undergo noticeable change, reflecting both a certain dissatisfaction with the existing methods of multilateral cooperation and an increasingly clear desire to take control, if not at the expense of, then at least in parallel with Japan. So, while in 1998 China opposed Japan's proposal for an Asian Monetary Fund, bringing indirect support to the IMF in its role as a source of financial aid, in 2000 it supported the Chiang Mai Initiative, which created a system of financial

16. Brazil, India, and Korea are among the "winners," while Europe was hit the hardest. Europe accounts for most of the losses, even if certain countries such as Poland and Spain won a few extra votes. Meanwhile, the United States lost nothing, because despite its significant influence on the global economy, it still remains under-represented within the IMF.

17. A "supermajority" such as this is necessary in order to pass reforms that affect both the growth and the redistribution of voting shares and the make-up of the institution's board of directors. The situation could be "unblocked" by separating the two aspects of reform from each other.

18. The term "revisionism," understood as a fundamental challenging of the established order, is borrowed from Barry Buzan, "China in International Society: Is Peaceful Rise Possible?", Chinese Journal of International Politics, Vol. 3, No. 1, 2010, pp. 5-36. 
aid between the countries of ASEAN+3 (China, South Korea, and Japan). Furthermore, just over ten years later, China pushed for multilateralisation, allowing the mechanism to become a veritable Asian monetary fund. ${ }^{(19)}$ Even if this initiative may at first have appeared largely symbolic, it received active support at the highest state level. (20)

Secondly, China would also attack the workings of the international monetary system, most notably by challenging the supremacy of the dollar. In China's eyes, other currencies should be accorded greater importance, in order to limit the "exorbitant privilege" held by the United States. After floating the possibility of resorting to a supranational currency inspired by Keynes' "bancor," China suggested that Special Drawing Rights (SDR) should be given the status of an international currency (21) and include the yuan as

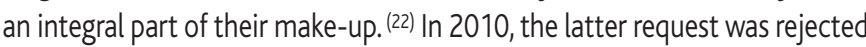
by the IMF on the basis that the yuan's partial convertibility meant that it did not fulfil all the necessary criteria.

But China did not give up. In the wake of the American budget crisis of 2013, certain Chinese experts re-entered the fray, suggesting that a supranational reserve currency should be created, and calling for fundamental reform of the international financial and monetary systems. Then in March 2015, armed with the yuan's increasing power in international transactions, (23) Chinese Prime Minister Li Keqiang submitted another formal request to IMF Managing Director Christine Lagarde, asking that the yuan be included in the calculation of SDRs. After what has been portrayed as an historic decision, China's request was finally accepted in 2015, allowing the yuan to become, as of October 2016, the fifth international reserve currency (but the third in order of importance). Given the fact that SDRs are rarely used, the value of this decision was essentially symbolic, but it created a way for China to become involved with an institution charged with supervising the global monetary system, and thus gain its support. (24) To deprive oneself of support from the economy with the largest currency reserves in the world would have made little sense.

At the same time, China pushed to internationalise its currency. The establishment of the Shanghai Pilot Free-Trade Zone in autumn 2013, permitting unrestricted convertibility of the Chinese yuan and payment in yuan for commercial exchanges, was done with this logic in mind, and helped to give the Chinese currency greater clout within the international monetary system. Likewise, the bilateral currency swap agreements recently passed by the People's Bank of China with the European Central Bank, but also with central banks in emerging economies such as Thailand, Nigeria, and Argentina, are intended to promote diversification of international currency reserves and the use of the Chinese currency on an international scale. Beyond internationalising the yuan, by seeking to impose the yuan as the equal of the dollar, China does indeed seem to be hoping for a fundamental reform of the international monetary system.

That being said, the recent turbulent behaviour of the Chinese financial markets and the authorities' nervous reaction to this suggests that the total liberalisation of the capital account and the complete convertibility of the yuan could still take some time, and gives rise to doubts about the yuan's ability to compete with the dollar.

\section{Institutional innovations}

The rise of this more aggressive stance has above all been visible through a whole series of institutional innovations. The first of these initiatives is the establishment of the BRICS New Development Bank, which to a certain extent constitutes an alternative to the World Bank. First conceived in 2013, the project was relaunched in 2014 on the occasion of the BRICS summit at Fortaleza in Brazil, leading to the institution being created in July 2015. (25) The NDB was given $\$ 100$ billion in capital. Its loans will notably be used to fund infrastructure works and sustainable development projects (both public and private) in BRICS and in other emerging economies.

Meanwhile, a shared currency reserve fund of $\$ 100$ billion was created (the BRICS Contingency Fund). China would contribute $\$ 41$ billion, Brazil, India and Russia would each contribute $\$ 18$ billion, and South Africa would contribute $\$ 5$ billion. Intended to provide member states with a means to combat financial crises or a speculative attack on their currency, to a certain extent this plan constitutes an alternative to the IMF.

But the real turning point in challenging the established order was without doubt the formation of the Asian Infrastructure Investment Bank (AIIB) at Beijing's instigation. The idea was first floated in autumn 2013, after which the AIIB project took shape with remarkable speed. Officially launched in 2014 when around 20 countries signed a draft treaty, the project became a reality with the publication of the institution's charter roughly eight months later. To widespread astonishment, the project met with huge success among a great many countries all over the world. Despite the United States putting pressure on its allies not to support the project, a number of Asia-Pacific countries (particularly South Korea and Australia) disregarded the warning, and 17 European countries (including Great Britain, Germany, France, Spain, Italy, the Netherlands, as well as Switzerland and Norway) also decided to join in the endeavour, bringing the total number of founding countries to 57.

As its name suggests, the purpose of this multilateral institution is to facilitate the funding of vast infrastructure projects in order to improve "connectivity" between the different countries in the Asian Region. According to the institution's charter, which was made public in spring 2015, the majority (that is, $75 \%$ ) of contributions must come from Asian countries. Quite naturally given its economic heft, China holds the lion's share, which amounts to $30 \%$ of the capital. China's dominant position is also reflected in the distribution of voting shares, even if the influence of major shareholders is limited by the fact that $15 \%$ of the voting shares are split equally between the founder members, irrespective of the size of their contribution.

19. The decision to shift to a multilateral arrangement was taken in December 2009 and came into effect in March 2010; for more details see Françoise Nicolas, "Economic Regionalism in East Asia: The End of an Exception?", in Sarah Tong (ed.), Globalization, Development and Security in East Asia (Vol. 2:Trade, Investment and Economic Integration), Singapore, World Scientific Publishing, 2014.

20. For instance, from President Hu Jintao, Premier Wen Jiabao, and Vice-Premier Zeng Peiyan; see Mikko Huotari, "A New Role in East Asian Financial Order," in Sebastian Harnisch, Sebastian Bersick, and Jörn-Carsten Gottwald (eds), China's International Roles: Challenging or Supporting International Order?, New York, Routledge, 2016, pp. 150-167.

21. For more details on the purpose and terms of this proposal, see Claude Meyer, La Chine, banquier du monde (China: Banker to the World), Paris, Fayard, 2014, Chapter 9; Michel Aglietta, "Un système monétaire international équilibré" (A balanced international monetary system), Économie politique, No. 45, January 2010, or Eswar Prasad, The Dollar Trap, Princeton, Princeton University Press, 2014, Chapter 12.

22. At that stage, the value of SDR was determined according to a basket of currencies that included the dollar, the euro, the pound sterling, and the yen.

23. According to data from SWIFT, in November 2014 the yuan became the fifth-most popular international payment currency, behind the dollar, the euro, the yen, and the pound sterling, but now ahead of the Australian and Canadian dollar.

24. See Barry Eichengreen, "China, the Responsible Stakeholder," Project Syndicate, 10 June 2015; LiGang Liu, "Why the West Should Welcome Chinese Yuan's Inclusion into the SDR," South China Morning Post, 8 June 2015; and Zhang Jun, "China's Pursuit of New Economic Order," Project Syndicate, 2 June 2015.

25. The first loans are anticipated in early 2016. 


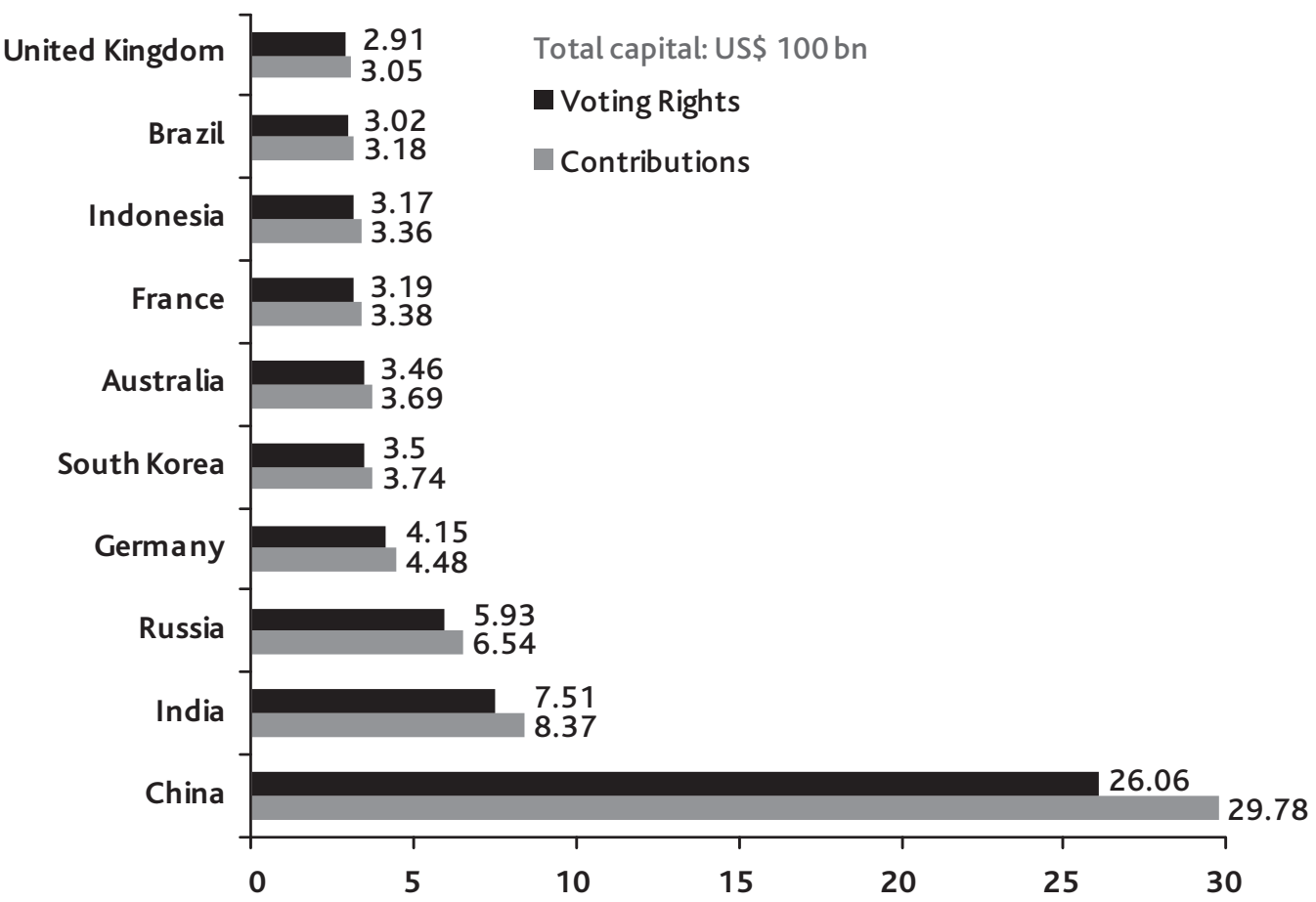

* Contributions are calculated based on the initial capital subscription.

Source: Korean Ministry of Strategy and Finance, quoted by CSIS (Center for Strategic and International Studies), "By the Numbers: China \& the Asian Infrastructure Investment Bank (AIIB)," cogitASIA, 7 July 2015, http://cogitasia.com/by-the-numbers-china-the-asian-infrastructure-investment-bank-aiib (accessed on 5 April 2016).

This is the reason that China only holds $26 \%$ of the total number of voting shares (see Graph 1). Since the decisions that affect major governance issues (especially revisions to the charter) require a majority of three-quarters in order to pass a vote, China possesses de facto (if not de jure) veto power. That being said, this rule does not apply to decisions regarding current affairs, for which a simple majority of votes cast would be enough.

One of the major characteristics of this institution is that it is dominated by developing or emerging Asian powers, rather than industrial economies. This is a clear reflection of the shifting balance of power, but not only in China's favour: $75 \%$ of the capital is in fact held by emerging or developing Asian economies, ${ }^{(26)}$ and nine of the 12 members of the management committee are Asian.

Alongside the AlIB, another project that deserves mention - despite having gone largely unnoticed - is the "Silk Road Fund," created on 29 December 2014. This 40-billion dollar fund, supported by two major Chinese banks (the Export-Import Bank of China and the China Development Bank, or CDB) as well as by two sovereign wealth funds that manage the country's foreign exchange reserves (the China Investment Corporation - $\mathrm{CIC}$ - and the State Administration of Foreign Exchange - SAFE), in some ways resembles the International Finance Corporation, which, as part of the World Bank group, is in charge of encouraging private sector development by acquiring equity in companies. (27) The goal for this new fund is to acquire equity in projects that fit into the vast plan for a new Silk Road (both by sea and on land, known as One Belt, One Road). The fund, which is exclusively Chinese (unlike the AllB), has been placed under the supervision of the People's Bank of China.

The first project to be financed by the Fund is the Karot Hydropower Project in Pakistan, the construction of which has been entrusted to a company called China Three Gorges South Asia Investment Ltd., a subsidiary of the China Three Gorges Corporation. This is the first in a series of clean energy construction projects in Pakistan, carried out under the aegis of a larger project: the China-Pakistan economic corridor, launched in May 2013 by Prime Minister Li Keqiang. The initiative envisages the construction of roads, railways, and energy projects that connect the deep-sea port of Gwadar, in south-west Pakistan, with the Xinjiang Uyghur Autonomous Region in north-western China.

Finally, during a visit to the United States in autumn 2015, President Xi jinping announced the creation of a $\$ 2$ billion development assistance fund to help the world's poorest countries and "put justice before interests." This initiative, while seemingly modest in scale, is without doubt a response to criticisms from the West that China is insufficiently involved in aiding the world's least developed countries, and that when it does grant economic aid, it consistently puts its own economic and strategic interests first.

\section{Interpreting China's initiatives}

\section{Multiple goals}

The institutional innovations supported by China (the New Development Bank, the development assistance fund, the AIIB, the BRICS Fund, and the Silk Road Fund) provide a means to circumvent the global economy's governance system, which has thus far been dominated by the major Western

26. This percentage could be brought down to $70 \%$ if the membership were to be enlarged beyond the 57 original founder-members.

27. Richard Kozul-Wright and Daniel Poon, "Development Finance with Chinese Characteristics," Project Syndicate, 20 May 2015. 
powers. These projects are indisputably part of a strategy that is no longer simply reformist, but revisionist. ${ }^{(28)}$ The same applies to Beijing's efforts to confer the yuan with international reserve currency status. That said, these initiatives could also reflect a desire on China's part to assume the responsibility that comes with increased economic influence, and to contribute to the existing order - or even to make it more effective - rather than challenge it. That is, in any case, its official stance. As China's Minister of Finance, Lou Jiwei, points out, "China needs to demonstrate its desire to assume greater international responsibility in promoting economic development in Asia, and beyond that, in the rest of the world." (29) This desire is perfectly in line with Xi Jinping's pronouncements on "the great renewal of the Chinese nation," which requires China's foreign policy to "strive to achieve success" (fenfa youwei 奋发有为). ${ }^{(30)}$

Still, make no mistake about it: above all, these projects directly serve to further China's interests, be they political or economic. The AlIB project is thus in perfect alignment with President Xi Jinping's flagship initiative known as "One Belt, One Road" (yidai yilu 一带一路) and indeed with the New Silk Roads (heading by land towards Central Asia, and by sea towards Southeast Asia), whose purpose is to strengthen rail, road, and maritime communications between China, East Asia, Central Asia, the Middle East, and Europe. It appears that the AllB is one of the tools being used to put this vast plan into action. In fact, both projects were launched simultaneously, even though an official connection between them has never been made. (31)

In the capacity of a traditional development bank, the AllB's objective is to fund infrastructure investments in the Asia-Pacific region as a matter of priority. But beyond the objective of aiding development, China - as the principal contributor - also intends to expand its influence in the region and to occupy a central role. In this respect, whatever China's leaders may claim, there is no doubt that the AIIB is establishing itself as a competitor to the Asian Development Bank, over which Japan has majority control.

Beyond the obvious geopolitical dimension, the AllB project also falls under the rationale of rebalancing the Chinese economy. ${ }^{(32)}$ In this respect, it is perfectly aligned with China's immediate interests (and therefore has every chance of succeeding, since the authorities will devote all their efforts to it). The authorities' prime objective is to be able to maintain a growth rate that is strong enough and steady enough to ensure social stability, and in doing so to ensure the regime's survival. Stabilising the Chinese economy is therefore a priority.

The problem that China must face up to is the following: having progressively accumulated currency reserves and low-yield external assets, it is now forced to increase its higher-yield assets. The launch of the AIIB should help to achieve that; in any case, it falls perfectly in line with the strategy China has employed thus far through swap agreements.

In the wake of the global financial crisis of 2008-2009, the People's Bank of China signed a series of bilateral currency swap agreements with a variety of central banks, particularly in emerging economies. As previously mentioned, this policy's most notable intention was to promote diversification among international currency reserves and the internationalisation of the yuan, but it would also allow the profitability of Chinese financial resources to be maximised. To understand this point, which is essential to the rebalancing of China's economy, it is necessary to examine the criteria that China used to select its partners for the swap agreements. Unlike the United States, which acted "conservatively" and focused on "reliable" partners while excluding countries that were seen as risky (for example, those that had al- ready defaulted, such as Argentina), China did not rule out these partners, and focused on the nature of the economic ties that it had with each recipient country when making its decision. The agreements, which were swiftly passed with trade partners, tended to reinforce the positive correlation that has been observed between the flow of Chinese direct investment in a country and China's importing of basic commodities from that same country. From the 2008 crisis onwards, it became clear that thanks to these agreements, a number of emerging countries in Africa, Asia, and Latin America were given access to infrastructures that were financed and built with Chinese resources in exchange for exporting commodities to China. In other words, with these swap agreements China pursued a rebalancing strategy that above all prioritised the profitability of its resources, thanks to its ability to access commodity goods and natural resources. These agreements were part of a broader strategy that could be described as mercantilist, and which combines the flow of direct investment abroad with the export of manufactured products and the import of commodities. Insofar as it will help to fund infrastructure projects in countries with trade links to China and with natural resources that are desirable for the Chinese economy, the AllB follows the same strategy. ${ }^{(33)}$

In the same way, the diversification of China's external assets in the form of FDIs, particularly via sovereign wealth funds or the Silk Road Fund, is intended to improve their return and contribute to the rebalancing process.

It is still too soon to say whether this strategy will pay off, and the fact that some of Beijing's partners are countries with a recent history of defaulting could carry a certain risk, even if China has partially protected itself by planning for repayments in kind further down the line.

\section{Initiatives taken through necessity, not choice}

China's aggressive stance over the last few years can be explained partly by the country's renewed sense of self-confidence and a growing awareness of the role that it can and must play in the world, and also by the fact that the world's established powers seem reluctant to admit that the balance of power has shifted.

Firstly, it should be noted that the reluctance in the West (and mostly in America) to recognise the growing influence of China and other large emerging economies, and to offer them the space that their size would appear to necessitate within the existing IFIs, ${ }^{(34)}$ will only encourage these economies to take a more offensive strategy and to establish systems of economic governance that are more in line with their interests and with the new balance of global power. Secondly, the international circumstances marked by the relative weakening of the United States in the wake of the

28. For more details on this subject, see Françoise Nicolas, "La Chine et les institutions économiques multilatérales, entre révisionnisme et statu quo" (China's role in multilateral economic institutions: Between revisionism and status quo), art. cit.

29. "This is China Assuming More International Responsibility for the Development of the Asian and Global Economies," Financial Times, 29 June 2015.

30. Yun Sun, "China's Preferred World Order:What Does China Want?", PacNet, No. 62, Pacific Forum CSIS, 21 September 2015.

31. On the other hand, the connection with the Silk Road Fund is much more explicit.

32. This plan to rebalance China's economy is outlined by Jia Qingguo, "One Belt, One Road: Urgent Clarifications and Discussions of a Few Major Questions," Renmin luntan, 19 March 2015; cited in David Cohen, "China's 'Second Opening': Grand Ambitions But a Long Road Ahead," China Analysis, June 2015.

33. For more details, see Joshua Aizenman, Yothin Jinjarak, and Huanhuan Zheng, "Chinese Outwards Mercantilism: The Art and Practice of Bundling," NBER Working Paper, No. 21089, April 2015.

34. A reluctance that is reflected in the United States' decision not to ratify the reform to voting shares in 2010 . 
2008-09 financial crisis may well have strengthened the emerging economies' determination to consider alternative solutions. Under these conditions, BRICS countries (and China especially) have launched a great many new initiatives, and their goals have become more resolute.

Moreover, since the so-called dominant powers - led by the United States - have not always been exemplary in their dealings with developing countries, they have managed to alienate some of these countries' senior figures, unwittingly providing China with a perfect opportunity to step in - and China has wasted no time in doing so. The fact that interventions by the World Bank in certain Southeast Asian (and African) economies were received very unfavourably explains why these countries were, at least to begin with, extremely receptive to the arrival of a new figure that seemed to better understand and share their concerns, and dealt with things in a way that seemed better suited to their needs. It is not certain that China has been able to take full advantage of these opportunities, because in many cases the developing partners are starting to become disillusioned. However, what is not in question is that China seems to have become fully aware that the multilateral approach is now a wiser choice than the previously preferred bilateral approach.

\section{Playing the multilateralism card}

Indeed, the AllB's multilateral nature is what sets it apart: this means that the initiative plays a greater structural role in the global economy, but also gives a clear signal that Beijing feels an increased sense of responsibility.

Henceforth, China will play a pivotal role in the global economy, and in development aid in particular. As a part of this, in spring 2015 the Chinese government was preparing to draw $\$ 62$ billion from its immense currency reserves (which amount to nearly $\$ 4,000$ billion in total) and invest them in the China Development Bank and the Export-Import Bank of China, both of which are principally intended to support its international aid policy. On a more general level, China's influence in funding development was now irrefutable: in Latin America for example, in the year 2010 alone, loans made by China through the two aforementioned banks were greater than loans from the World Bank, the Inter-American Development Bank, and the Export-Import Bank of the United States put together. ${ }^{\left({ }^{35}\right)}$ Clearly, therefore, China was already indirectly influencing the global economic order.

Under these conditions, China's transition to a multilateral approach is truly remarkable. It is, in fact, one way in which the AllB amounts to a revolution, because for the first time, China is seeking to exert its influence through multilateral channels, rather than through its preferred national agents (in particular the Exim Bank of China and China Development Bank). To oppose that would mean encouraging China to steer back onto its old bilateral course, and without any safeguards, at that; so there is little doubt that the multilateral option is the lesser evil. In this respect, the Silk Road Fund is potentially a more dangerous tool, because it serves China's interests more directly.

By making the transition to a multilateral approach, the Chinese authorities are showing that they are prepared to give up going it alone, and indeed even to accept a certain amount of advice from their peers. It is therefore highly likely that the reservations expressed by a number of Western authorities (that the AlIB does not conform to established practices) have been exaggerated. Within this institution, it is especially in China's interests to establish its credibility as a responsible member of the international system. What's more, by making use of this institution to protect its own interests,
China is in fact acting no differently from the way the United States and Great Britain before them behaved when they dominated the global economy.

\section{A successful charm offensive}

Finally, it is worth stressing that the success of the AlIB is almost certainly assured, given the support it has received not only from industrial countries, many of whom are allies of the United States, but also from various other nations within the region, be they small developing economies such as Cambodia, for example, which sees in the AIIB a way to avoid face-to-face confrontation with the World Bank, of whom it is less than fond, or emerging economies such as Indonesia, which consider China's ambitions in the region to be perfectly in line with their own desire to wield greater influence within the region's balance of power. ${ }^{(36)}$

Beyond China's ability to convince its partners that they, too, can benefit from its project, its success can also be explained by one simple fact: the AlIB is responding to a real demand, so wide is the gulf between Asia's infrastructure requirements (estimated by the Asian Development Bank - ADB - to be $\$ 8,000$ billion between now and 2020) and the resources available via the World Bank and the ADB.

In summary, the AllB allows China to kill several birds with one stone: it can prove its willingness to assume the responsibilities that come with its status as a superpower, it can win favour with certain neighbouring countries and economic partners, and it can also recycle its trade and fiscal surpluses in a profitable way.

The United States undoubtedly made a mistake in deciding to criticise China's initiative so publicly. By putting pressure on their Western partners, and not only on them, the American government (which has been criticised by a number of experts and political leaders such as Robert Zoellick, Ben Bernanke, and Joseph Stiglitz, (37) to name only a few) ended up giving worldwide publicity to China's proposal, and what's more, made the proposal appear as a challenge to the overarching influence of the United States and IFIs under the influence of the West. Beyond a lack of tact, America's reaction mainly ended up drawing attention to its own weaknesses, and pushed Beijing's success even further into the spotlight.

\section{Conclusion: Chinese pragmatism is alive and well}

The dynamic of China's increasing power and growing influence over the global economy is now an undeniable reality. The various initiatives that China has recently employed amount to a kind of institutionalisation of this influence, but it must be noted that even without these initiatives, China was already a force to be reckoned with in the global economy.

As a result of reluctance in the West, and in America in particular, to recognise this new state of affairs, China was forced to take the initiative itself,

35. Based on figures cited by Kevin Gallagher et al., The New Banks in Town: Chinese Finance in Latin America, Global Development and Environment Institute, Tufts University, February 2012. In addition, China recently promised to invest $\$ 250$ billion over the space of ten years in Latin America and the Caribbean.

36. In fact, President Jokowi considers the maritime Silk Road to be perfectly in accordance with his own strategy to turn Indonesia into a "global maritime axis."

37. David Pilling and Josh Noble, "US Congress Pushed China into Launching AllB, Says Bernanke," Financial Times, 2 June 2015; Joseph Stiglitz, "Why America Doesn't Welcome China's New Infrastructure Bank," The World Post, 13 April 2015; Robert Zoellick, "Shunning Beijing's Infrastructure Bank Was a Mistake for the US," Financial Times, 7 June 2015. 
but as we have seen, its goal is not so much to revolutionise the global economic order as it is to make it more efficient. But for China, the more important issue is to equip itself with the resources that will allow it to pursue its own development and prove itself a responsible contributor on the global economic scene. The fact that the Indonesian President voiced his support of the AllB at the summit marking the $60^{\text {th }}$ anniversary of the Bandung Asian-African Conference ${ }^{(38)}$ suggests that this new project could fall in line with the same approach: that of challenging the established order and allowing developing countries to take control of their own destiny. However, this may not be the case. At this stage, the priority for China is to pursue its own interests, but its strategy does not appear to include setting any regulations. In this respect it is different from the United States, which is hoping to create a new regulatory framework for international trade in the broadest sense of the term via the Trans-Pacific Partnership (TPP) and the Transatlantic Trade and Investment Partnership (TTIP).

That being said, China's recent tactics reflect a clear desire not to let the United States alone dominate the global economy, and on the contrary, to take steps to establish "new systems of governance and international co- operation." (39) These systems are, however, as yet undefined, and it would seem that they will solidify over time. Beijing is taking advantage of its assets (and its financial clout in particular) to better position its chess pieces, but this remains an experimental strategy, with an end goal that is ultimately vague (or perhaps has been deliberately allowed to appear vague). The all-fronts offensive of the New Silk Road and "One Belt, One Road" is typical of this strategic vagueness, even if it is built upon a plethora of entirely tangible projects. By means of these projects, China could succeed gradually in becoming a central figure of global economic governance. Only time will tell whether China's pragmatic strategy will win out over Washington's more ideological approach, and whether a genuinely new global economic order emerges as a result.

\section{Translated by David Buchanan.}

I Françoise Nicolas is director of the Centre for Asian Studies at the Institut français des relations internationales (IFRI, French Institute of International Relations), Paris.

IFRI, 27 rue de la Procession, 75015 Paris (nicolas@ifri.org).
38. The 1955 Bandung conference signalled a marked increase in the demands of newly independent African and Asian nations, demands that would eventually fuel the Non-Aligned Movement.

39. See the original English version of "Vision and Actions on Jointly Building Silk Road Economic Belt and $21^{\text {st }}$ Century Maritime Silk Road," NDRC/MFA/MOFCOM, 29 March 2015, which deals with "new models of international cooperation and global governance." 